
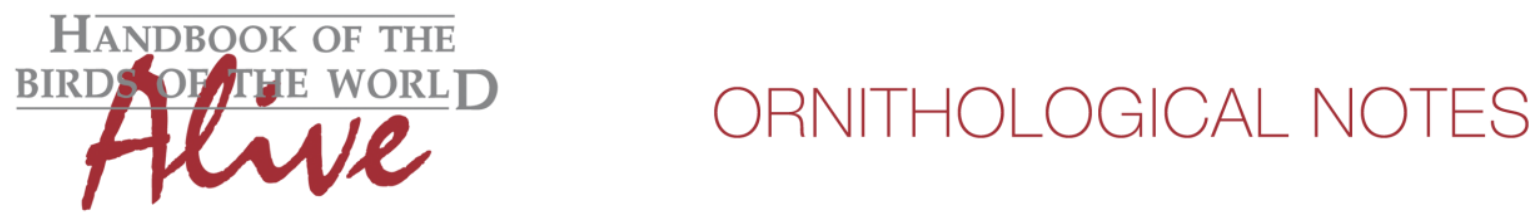

\title{
Notes on the vocalizations of Black-throated Tody-tyrant (Hemitriccus granadensis)
}

\author{
Peter Boesman
}

In the following we briefly analyze and compare voice of the different races of Black-throated Tody-tyrant (Hemitriccus granadensis). We also try to quantify the extent of any vocal differences using the criteria proposed by Tobias et al. (2010), as a support for taxonomic review. We have made use of sound recordings available on-line from Xeno Canto (XC) and Macaulay Library (ML).

Main vocalizations are a short series of well-spaced notes (usually rising and falling in pitch, and accelerating/decelerating), and a much faster trill.

pyrrhops seems to utter more the short series of notes, granadensis mainly the trill, while lehmani again the short series of notes (based on the fairly low number of available recordings). There are no recordings available of the Venezuelan races (a recording from $W$ Perija (ML204681) is so different that I have not included it in the analysis, as identification should be checked more thoroughly). Two recordings of caesius are of the short series.

We have measured some basic sound parameters for both vocalization types:

$\begin{array}{ll}\begin{array}{l}\text { pyrrhops } \\ \text { note series }(\mathrm{n}=8)\end{array} & \\ \text { lowest max. freq. } & 1800-3000 \mathrm{~Hz} \\ \text { highest max. freq. } & 2550-3300 \mathrm{~Hz} \\ \text { note length } & 0.065-0.09 \mathrm{~s} \\ \text { pace } & 0.14-0.25 \mathrm{~s} \\ \text { trill }(\mathrm{n}=2) & \\ \text { pace } & 0.08-0.096 \mathrm{~s} \\ \text { max. freq. } & 2170-3600 \mathrm{~Hz}\end{array}$

caesius

note series $(n=2)$

lowest max. freq. $\quad 1500-1800 \mathrm{~Hz}$

highest max. freq. $\quad 2000-2140 \mathrm{~Hz}$

note length $\quad 0.065-0.10 \mathrm{~s}$

pace $0.13-0.40 \mathrm{~s}$

$\begin{array}{ll}\begin{array}{l}\text { granadensis/lehmanni } \\ \text { note series }(\mathrm{n}=3)\end{array} & \\ \text { lowest max. freq. } & 1800-2050 \mathrm{~Hz} \\ \text { highest max. freq. } & 2050-2400 \mathrm{~Hz} \\ \text { note length } & 0.065-0.08 \mathrm{~s} \\ \text { pace } & 0.19-0.49 \mathrm{~s} \\ \text { trill }(\mathrm{n}=3) & \\ \text { pace } & 0.06-0.08 \mathrm{~s} \\ \text { max. freq. } & 2600-3000 \mathrm{~Hz}\end{array}$



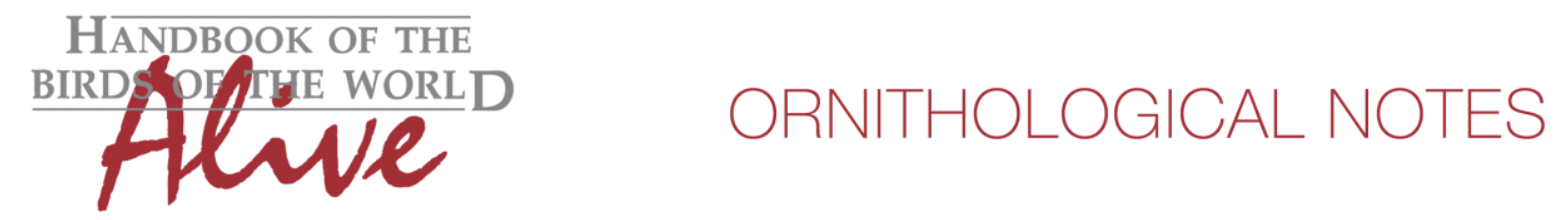

Overall vocalizations are quite similar.

The note series of pyrrhops is distinctive in having upslurred notes, and as a consequence reaches higher frequencies. Somewhat surprisingly, southern race caesius is much more similar to northern races (although only 2 recordings available)(Fig. 1).

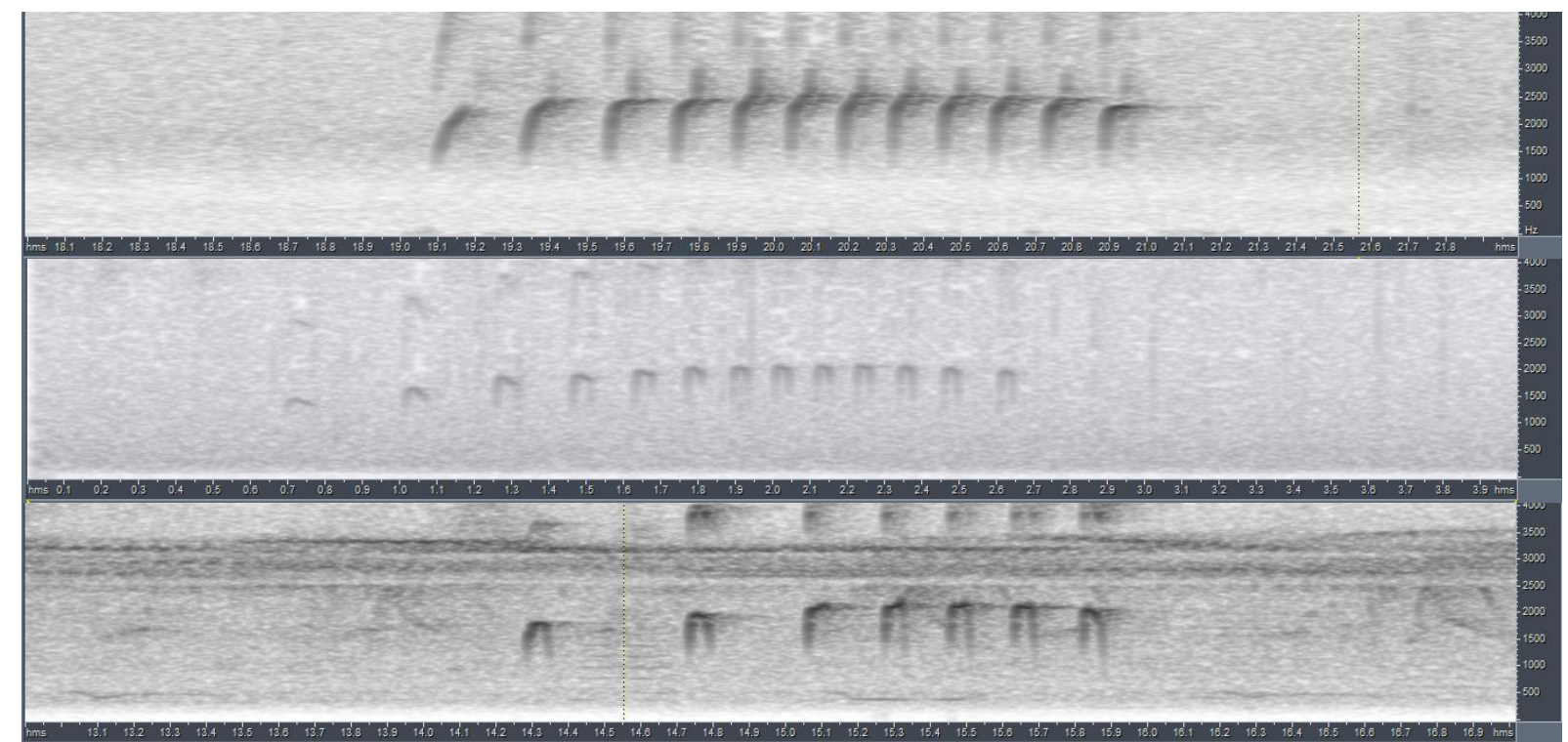

Figure 1: Typical examples of homologous vocalizations of pyrrhops (top), caesius (middle) and lehmanni (bottom).

It is quite remarkable that the vocal difference of pyrrhops vs. all other races including caesius coincides with the racial difference in lore colour.

As max. freq. and/or note shape are the only obvious differences, a vocal score of 2-3 could be given to pyrrhops vs. all others.

It is further intriguing that granadensis seems to utter (almost ?) exclusively the trill.

This note was finalized on 31st August 2015, using sound recordings available on-line at that moment. We would like to thank in particular the many sound recordists who placed their recordings for this species on XC and ML.

\section{References}

Tobias, J.A., Seddon, N., Spottiswoode, C.N., Pilgrim, J.D., Fishpool, L.D.C. \& Collar, N.J. (2010). Quantitative criteria for species delimitation. Ibis 152(4): 724-746.

\section{Recommended citation}

Boesman, P. (2016). Notes on the vocalizations of Black-throated Tody-tyrant (Hemitriccus granadensis). HBW Alive Ornithological Note 249. In: Handbook of the Birds of the World Alive. Lynx Edicions, Barcelona. (retrieved from http://www.hbw.com/node/932247 on 1 October 2016). 